\title{
Sir William Osler and his Welsh connections
}

\author{
John Cule
}

University of Wales College of Medicine, Heath Park, Cardiff CF4 4XN, UK.

'If you would know a man you must first know his connections.'

This nationally practised Welsh aphorism is said to derive from the need to have called on all close and distant relations to the ninth affinity to strengthen pleadings under the Ancient Laws of Wales.

\section{The 'ancient Welsh cozens'}

The Osler family had Cornish roots and therein lies a firm if distant Welsh connection. No less an authority than the learned $\mathrm{Dr}$ Thomas Phaer of Cilgerran (1510?-1560), writing of the boisterous ball game of knappan - of which we shall learn more anon - refers to 'our ancient cozens the Cornishmen who have the selfe same exercise amonge them yett observed, which they call hurlinge'. ${ }^{1}$

William Osler's grandfather lived in Falmouth, whence his father Featherstone Lake Osler moved to Canada with his young bride, Ellen Free Pickton. She was a native of London, but bore a distinguished Welsh name. William was the youngest of their family of nine, and was born in the parsonage at Bond Head in Tecumseth County in the backwoods of Upper Canada.

Uncle Edward was the eldest of the nine children of Grandfather Osler. He was a favourite uncle, of whom WO wrote 'we cherished an amazing veneration'. And small wonder, for his books were available for William to read from the shelves of his father's study, and Uncle Edward had many of the qualities that William also inherited. ${ }^{2}$

Edward Osler (1798-1863) was a naturalistdoctor. He qualified M.R.C.S. from Guy's Hospital where he was a medical student at the same time as Keats, and he too was a poet, though perhaps not quite of the same calibre. He wrote mainly hymns and psalms, being of a somewhat religious turn of mind. In a broader literary way, he was editor of the Royal Cornwall Gazette, published at Truro, where he practised medicine from 1840 until his death in 1863. Earlier he had been a naval surgeon and still earlier was a hospital surgeon at Swansea.

Correspondence: J. Cule, M.D., M.A., F.R.C.G.P., Abereinon, Capel Dewi, Llandysul, Dyfed SA44 4PP.
He was evidently proud of his association with the town for on the title page of one of his books, The Church and Dissent, Considered in their Practical Influence, London, 1836, he describes himself as 'formerly one of the surgeons to the Swansea Infirmary, and Surgeon to the Swansea House of Industry.' In 1911, the Regius Professor of Medicine at Oxford unveiled a brass tablet 'To the memory of Edward Osler, M.R.C.S., F.L.S. House Surgeon of this Hospital in $1825^{\prime} .^{3}$

\section{Griffith Evans and William Osler}

When young William Osler was still a medical student at Toronto, he met a Welshman for whom he was to develop a great regard. Indeed, he later recognized his genius at a time when practically no-one else did. Griffith Evans (1835-1935) was stationed there as a veterinary surgeon to the artillery during the time of the Fenian Rising. Because of his interest in microscopy he was invited by Dr James Bovell, one of Osler's teachers at the university, to help in the preparation of specimens. A friendship began between them in 1867 , at the time of their meeting in Bovell's rooms in Trinity College. Evans described Osler as 'a young man of $\frac{7}{0}$ great charm' and helped him on microscope technique, advising him to treat the instrument gently 'as you would a lady'. Griffith Evans had previously been stationed in Montreal, where this industrious army officer had used his posting to qualify M.D., C.M. (McGill) with a thesis on tuberculosis, in addition to his veterinary diploma. ${ }^{4}$ He read widely in medical science when the controversy over the significance of bacteria was at its height and himself came to rank amongst the pioneeers of the Germ Theory (Figure 1).

(C) The Fellowship of Postgraduate Medicine, 1988 


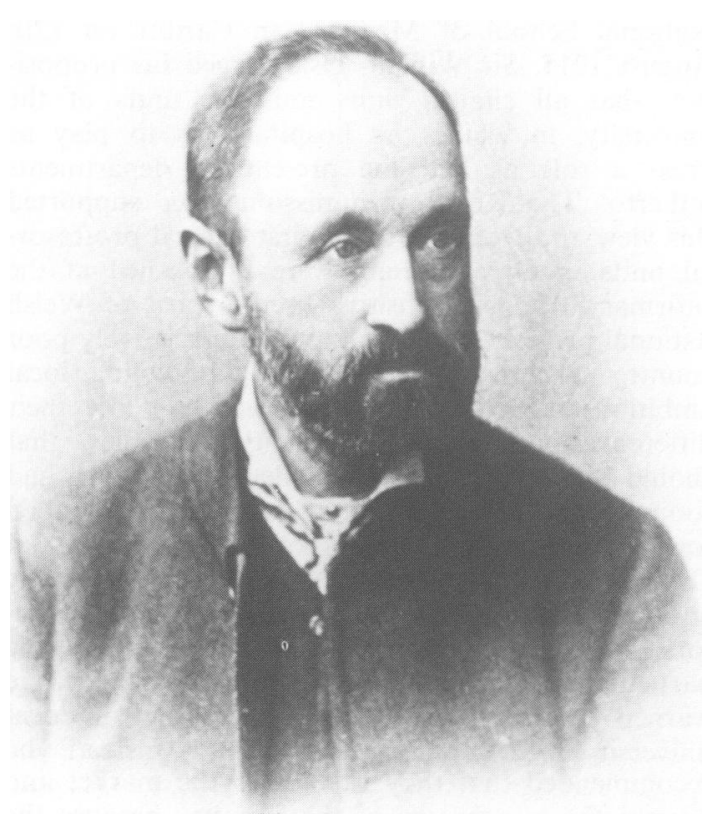

Figure 1 'Griff'. Griffith Evans, M.D. (McGill). Reproduced from Annals of Tropical Medicine \& Parasitology, 1918: 12, with permission.

Osler, Evans and Koch shared a common interest in the natural history of tuberculosis. In 1882, Robert Koch (1843-1910) published his brilliant classical paper describing the infectivity of tuberculosis. It is a well contrived and simple demonstration of the nature and spread of the tubercle bacillus. It has often been said that Koch never formally set out the famous 'postulates', which had already been suggested by Jacobe Henle (18091885). ${ }^{5}$ The criteria are, however, clearly stated in Koch's paper of 1882. 'To prove that tuberculosis is a parasitic disease, that it is caused by the invasion of bacilli and that it is conditioned primarily by the growth and multiplication of the bacilli, it was necessary to isolate the bacilli from the body; to grow them in pure culture until they were freed from any disease-product of the animal organism which might adhere to them; and, by administering the isolated bacilli to animals, to reproduce the same morbid condition which, as known, is obtained by inoculation with spontaneously developed tuberculous material.'6

Griffith Evans did not have the laboratory facilities which were at the disposal of Professor Koch. His work was literally in the field, where he first described and demonstrated the pathogenicity of the trypanosome. He searched for the causative organism in the blood of infected animals known to be suffering clinically from Surra. This invariably fatal disease of horses was of major economic importance to the British Army in India. In September and October, 1880, at Dera Ismail Khan in Punjab, he worked with the microscope 'for many hours a day out-of-doors at the sick lines, or else in a stable, when the thermometer was $82^{\circ} \mathrm{F}$ within a cool bungalow, and the sun pouring down its rays through a cloudless sky upon the surrounding bare sandy ground'. The flies were an added torment, crowding on the stage of the microscope, disturbing his vision, soiling the lenses and swarming all over his face. ${ }^{7}$ Nevertheless, despite these trials, he succeeded in inoculating healthy horses with trypanosome laden blood from infected animals and reproducing the disease. In the eloquent prose of his report he concluded 'There is, therefore, some virus in the blood, which, when it is transferred into a healthy animal, is as sure of growth and propagation as if we introduced seeds into a garden, or the roe of a fish into a suitable stream: the like reproducing its like, and no other.' ${ }^{8}$ For reasons largely unconnected with science, his work was interrupted. His suggestion that Trypanosoma evansi could possibly cause illness in humans has only recently been confirmed in its taxonomic identity with T.brucei, the cause of sleeping sickness, so that by the rules of Zoological Nomenclature, $T$. brucei must henceforth be known as T. evansi. ${ }^{9}$

In 1918, WO wrote to Griffith Evans thanking him for sending his papers to his alma mater, the university of McGill. He promised to have the Surra paper 'nicely bound and go in the shelf with Manson, Ronald Ross, Bruce and Cunningham' AI Anglo-Indian Co. 'Tis a fine bit of work and will carry the name of Griffith Evans a long way down the track of time'. ${ }^{10}$

Many, many years after Griffith Evans's major work, in fact at least 30, WO addressed the Cardiff Medical Society and asked if anyone there knew of Griffith Evans and his achievements. At first, as he expected, no one responded and then a diminutive lady, Dr Erie Evans, rose to her feet and announced that she was his daughter. Many, many, many years later at a lecture on Griffith Evans to the Honourable Society of Cymmrodorion at the Manson theatre of the School of Tropical Medicine, a member of the audience rose to her feet to claim affinity as his granddaughter, Jean Ware. As he himself reflected, when well on in years, his life work still in relative obscurity, 'Os mynni glod bid farw' - 'If you would seek fame, you must first die.'

\section{The Welsh National School of Medicine}

For Wales herself, WO's great contribution was his 
enthusiastic work in the founding of the Welsh National School of Medicine. He had shown an interest as early as 14th November 1905, the year in which he took the Chair of Medicine at Oxford. He was then 56 years old and spoke at University College, Cardiff showing concern for the financial neglect of its pre-clinical medical school, but personally encouraging the medical students when he dined with them that evening. He saw the possibilities and the need for a teaching hospital. Three years later he was asked to open the 'Electrical Pavilion' in the new Out Patient Department at the old Infirmary. On his way to give his address he was handed a magnificent golden key - a replica of a key of the Charles First period - by the architect, Mr Edwin Seward (Figure 2).

With his usual sense of mischief, he said in his speech that he had just met a gentleman who had asked him to accept something on behalf of the Institution. He pretended neither to be sure of the identity of the architect nor of the offering. 'But let us see if we can discover the nature of this very acceptable gift.' $\mathrm{He}$ then placed the wood and leather case under the X-ray tube and revealed the secret, observing that it would, of course, require exposure to daylight to determine any detail. They key is still preserved at the school. ${ }^{11}$

At the inaugural proceedings for the Welsh

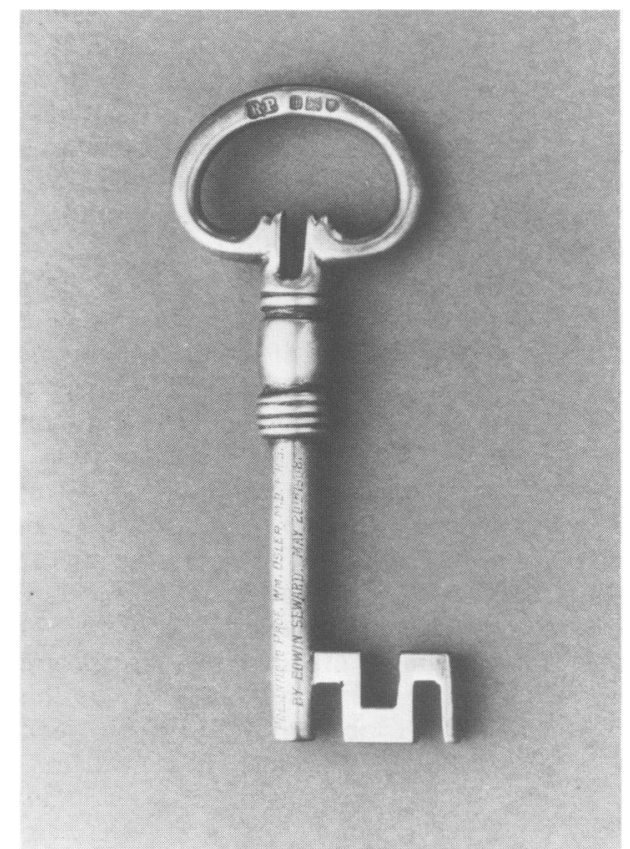

Figure 2 The golden key presented to Sir William Osler at Cardiff. From University of Wales College of Medicine, with permission.
National School of Medicine in Cardiff on 12th August 1915, Sir William Osler urged his proposition that all clinical units must be units of the university, in which the hospital was to play as great a role as had the pre-clinical departments hitherto. The Royal Commission later supported this view and from 1921, the first clinical professorial units in Great Britain were established at the Infirmary. He was sensitive to the spirit of Welsh national pride in this 'small and comparatively poor country' and which had led to conflicting local of ambitions. His listeners were urged to settle their $\vec{\circ}$ differences within one University of Wales, that should retain its constituent colleges and which had $\vec{\omega}$ room for only one school of medicine. He called for democracy on the lines of the universities of Oxford and Cambridge, where all academic appointments were made by small boards of elec- $\$$ tors, each of whom would be an expert in the of particular subject in which there was a vacancy. He warned against the danger of having 'a local of university with only Welsh brains'. Instead, he ${ }_{0}^{\infty}$ recommended that they went into the market and bought the best brains of the country, because the best brains of the country were not one whit too good for Wales.' ${ }^{2}$

It was therefore a great pleasure for Professor $\mathrm{Sg} \ddot{\emptyset}$ William Osler to be invited in April, 1916, to serखe on a Royal Commission, which gave him the opportunity to take part in the establishment of complete clinical and pre-clinical Welsh National School of Medicine. The terms of the Commission were to enquire into the organisation and work of the University of Wales and and its constituent colleges. It was to be a task of some complexity in satisfying the desire for individual autonomy in a federal structure.

Lord Haldane, who was chairman of the Commission, found Sir William to be a tower of strength in framing and negotiating a scheme for an adequate college of medicine in the reformed university'. There was a paramount need to establish independence for the medical school: a need strongly supported by Sir William, for it was o evident that University College, Cardiff not only wished to retain the control it already had over the $\frac{T}{0}$ pre-clinical school, but it had the undoubted advantage in any argument that it owned the land $N$ on which the existing medical college stood. Sir N William was believed by Lord Haldane to have N influenced the result by persuading a local lady, $\omega$ Miss Emily Talbot of Margam, to give $£ 30,000$ as an endowment for the new college. The money was for a Chair of Preventive Medicine and one of the conditions was that Sir William named the committee of appointment for the new professor. There was also reference to the 'anonymous donor' of a 
magnificent sum. To establish the professorial unit system an approach was made to the Chancellor of the Exchequer for support of the building fund. To encourage him, the 'anonymous donor' had made an important condition 'that the grant made by the Treasury shall in the opinion of Sir William Osler the Regius Professor of Medicine at Oxford be an adequate one for a first-rate, up-to-date mèdical school'.13,14 WO's breadth of effort fully justifies the comments of another member of the Commission, Sir Henry Jones, that they 'gladly leaned on his experience and strong common sense not only in matters that concerned medical education, but were largely influenced by his liberal views on education in general. Moreover, the gentle playfulness at the back of his mind made him as ideal a committeeman as a companion, and because of his sympathetic understanding of the Welsh people their debt to him is deep.'15

\section{Sir William Osler and Mr Lynn Thomas (Figure 3)}

On his joining the Commission, Sir William immediately began an active campaign to rally Welsh support for the new school and chose as his principal aide de camp a well known Cardiff surgeon, Mr Lynn Thomas, later to become Sir John

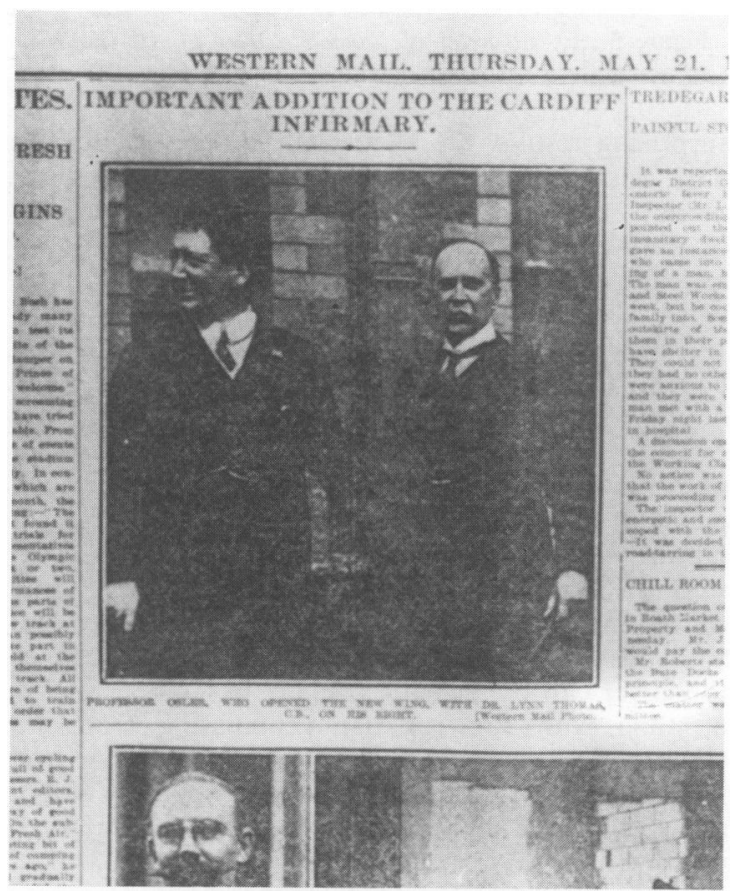

Figure 3 Professor William Osler and Mr John Lynn Thomas at the Cardiff Infirmary, 1908. From the Western Mail with permission.
Lynn-Thomas (1861-1939). WO seems to have been greatly impressed by $\mathrm{Mr}$ Thomas, who is certainly worthy of a brief diversion. Born the son of a farmer, Evan Thomas of Cwmgefeile, Llandysul, he had won the Hutchinson Prize for his essay on fractures of the skull in 1890, four years after qualifying M.R.C.S. He was regarded as having an excellent operating technique, with a particular interest in thyroid and prostate surgery. He had commanded the Welsh Hospital in South Africa during the Boer War, for which he was awarded the C.B. After his return home, he founded the Prince of Wales Hospital in Cardiff for limbless soldiers and sailors, which was to become an important orthopaedic centre. He became C.M.G. in 1917 and after a distinguished career was made K.B.E. in 1919.

In April, 1916, Mr Lynn Thomas had a letter from Sir William Osler.

Monday

\section{Dear Thomas,}

Get your mind on the question of a national post-graduate scheme in connection with the school. The Commission will visit Wales in June (end of) and I should like to hold meetings of the profession at Bangor, Aberystwyth and Cardiff. Please help in this when the time comes. We could bring the Tuberculosis men $\& C .^{15}$

This was during the early years of the King Edward VII Welsh National Memorial Association, whose first president was Dr Marcus Paterson, formerly superintendent of Frimley Sanatorium. The problem of tuberculosis in Wales was a formidable one. Of 348 sputum specimens obtained from public footpaths in Swansea in 1914, tubercle bacilli had been found in $57 \% .{ }^{16}$

The next letter was a typically encouraging one, but preparing the ground for the next step forward. He expressed his pleasure with the efforts of $\mathrm{Mr}$ Thomas.

You are moving along! The report of the Hospital meeting shows a good spirit - I was glad to see the suggestion of an Election Committee. How can we get in touch with the Profession whose confidence should be sought? Is there not a Principality Branch of the B.M.A.? It will be a great matter to have everything cut and dried for the commission. The Hospital must be made to feel that it is the Medical School for the last three years. Yours sincerely, ${ }^{15}$ 
Osler was in his sixty-seventh year, but he busied himself with the fostering of enthusiasm by active discussion with the doctors of Wales, which he saw as a necessary preliminary to a successful foundation. He wrote again to Thomas to say that he expected to be in Cardiff on June 21st and 22nd and hoped that a meeting of the medical profession could be arranged for a full and free exchange of views. He proposed to travel to the colleges of Aberystwyth and Bangor in the following week and wished to know whom he should approach to organise meetings. Perhaps Thomas himself would 'come up there and play the missionary'. Osler wished 'to get the entire profession of the principality interested in the medical school.' The emphasis was to be on the people who were going to do the work. 'Pick your men - men are the important thing. The day is long past when big buildings mean a big university or a big college - pick them for two things, for their enthusiasm and for their work as researchers.' ${ }^{17}$

\section{Sir John Lynn-Thomas}

After distinguished careers the thoughts of medical men oft turn to medical history, occasionally with

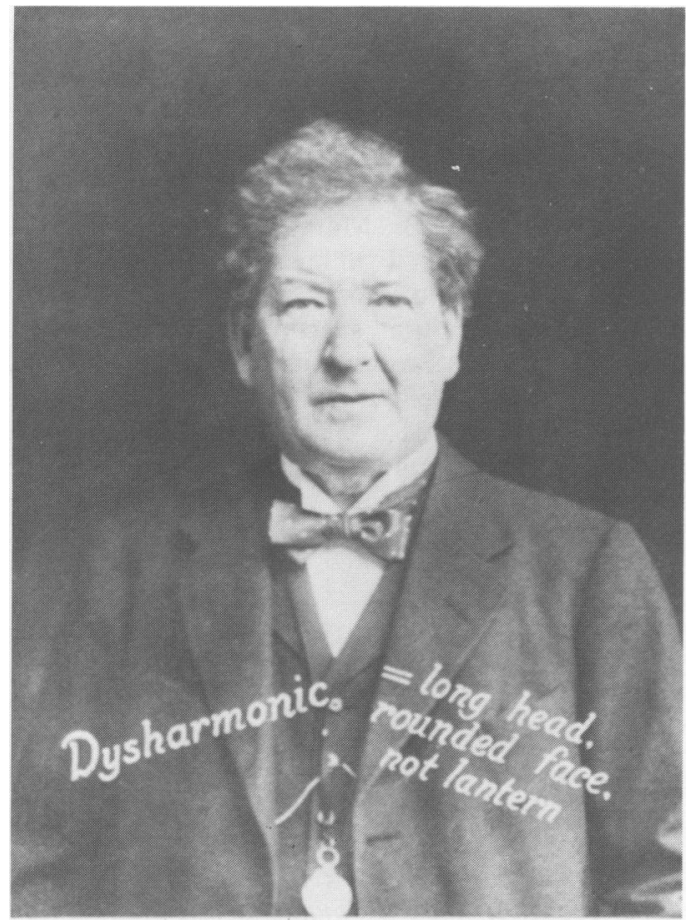

Figure 4 Frontispiece to 'Key of All Wales', with permission of the Western Mail.

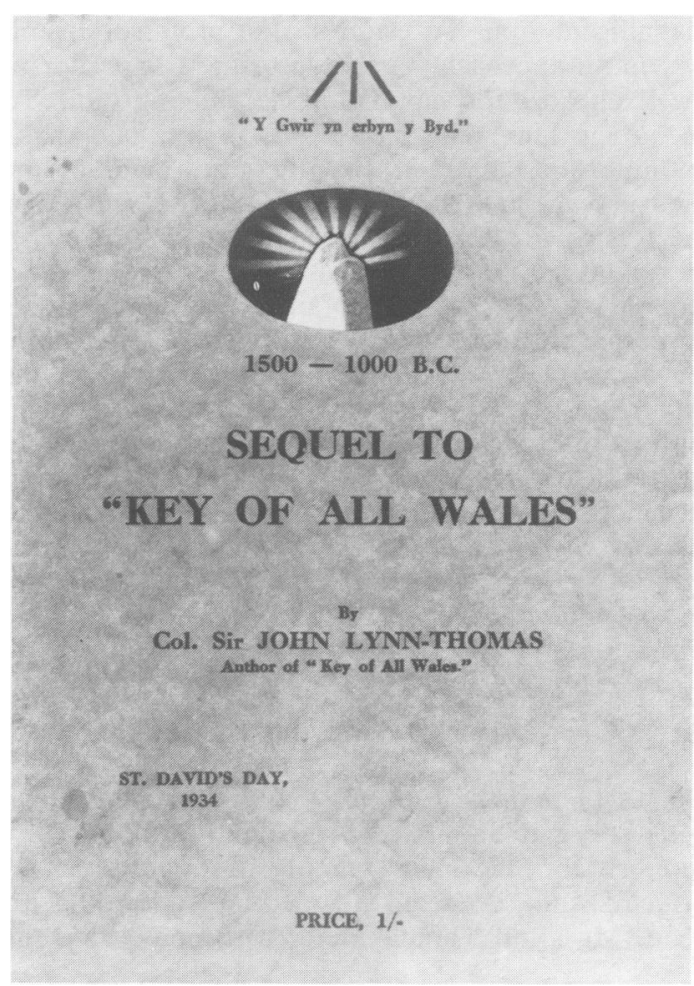

Figure 5 Front cover of Sequel to 'Key of All Wales' showing the oval space.

surprising results. Sir John later wrote some original, but eccentric papers on his archaeological 'finds', on which he based his theories of the origins of the Welsh in the area between Cardigan Town and the mansion of Llwyndyrus at Llechryd, to which he retired in 1921. Encouraged by The Western Mail, Sir John published two extraordinary books. The first was called 'Key Of All Wales' in South-West Cardiganshire, Cardiff: 1932 and dedicated to H.R.H. the Prince of Wales. A photograph of Sir John appears anonymously in the frontispiece, demonstrating an 'Estuarian Type' of mixed Nordic and Mediterranean features (Figure 4). The second book is arguably an even stranger one called Sequel to 'Key Of All Wales', published on Saint David's Day, 1934. Through an oval space in the cover can be seen the roughly pyramidal top of a stone with rays of light emanating from it. (Figure 5). When the book is opened the whole rock is revealed, looking remarkably like a Welsh stone gate-post. From behind protrude an uplifted right arm and a firmly placed right leg, which possibly belong to Sir John (Figure 6).

The contents reveal the material of a bitter feud with the Cambrian Archaeological Association, 
which he felt was bent on preventing an unbiased assessment of his views. His thesis of the Phoenician Occupation of the countryside around Llechryd and Cenarth was based on three 'discoveries'. First, his belief that he had found certain 'incised' stones, which he imaginatively interpreted as showing the existence of an ancient civilisation on the site. Second, the survival of a pygmy race, which demonstrated an African origin for the Estuarians as Sir John called them, or the Cardis as they are more popularly known. The testimony for this could be studied in the photograph of Teiliwr bach Dihewyd (the little tailor of Dihewid), 44 inches in height, with his wife of five foot five inches and seven normal sized children (Figure 7). The third

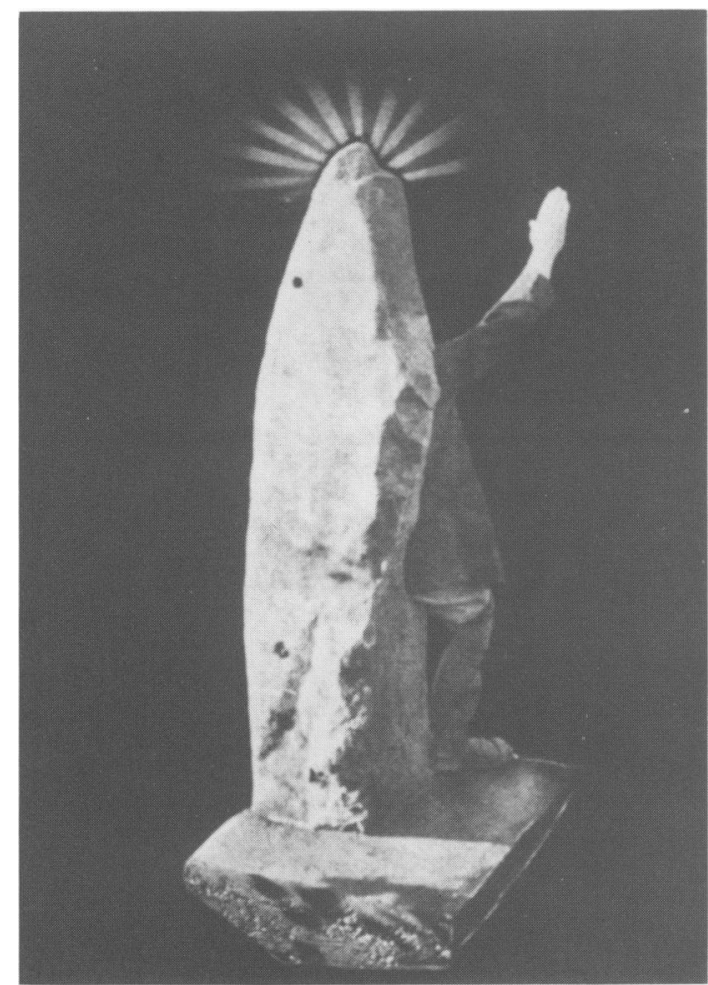

Figure 6 The Welsh Gate Post. Sir John has captioned this - 'Has two burnished facets and left eye reflecting sun-rays at back of head. Found November 5 th, 1932, in a ruined temple of nine megaliths sculptured, some inscribed, similar to over fifty found mostly in K.A.W. One of the two holes near lower end has iron broken in it whilst the third, below right eye, shows no sign of use. Inferior mouthed with tail like bonnet headed Shark, not Beaumaris, bifid, was embedded in concrete, 7ft 8in of Precelly granit.' (K.A.W. is Sir John's abbreviation of Key of All Wales). From Sequel to 'Key of All Wales', 1934, bearing the imprint of Western Mail, with permission.

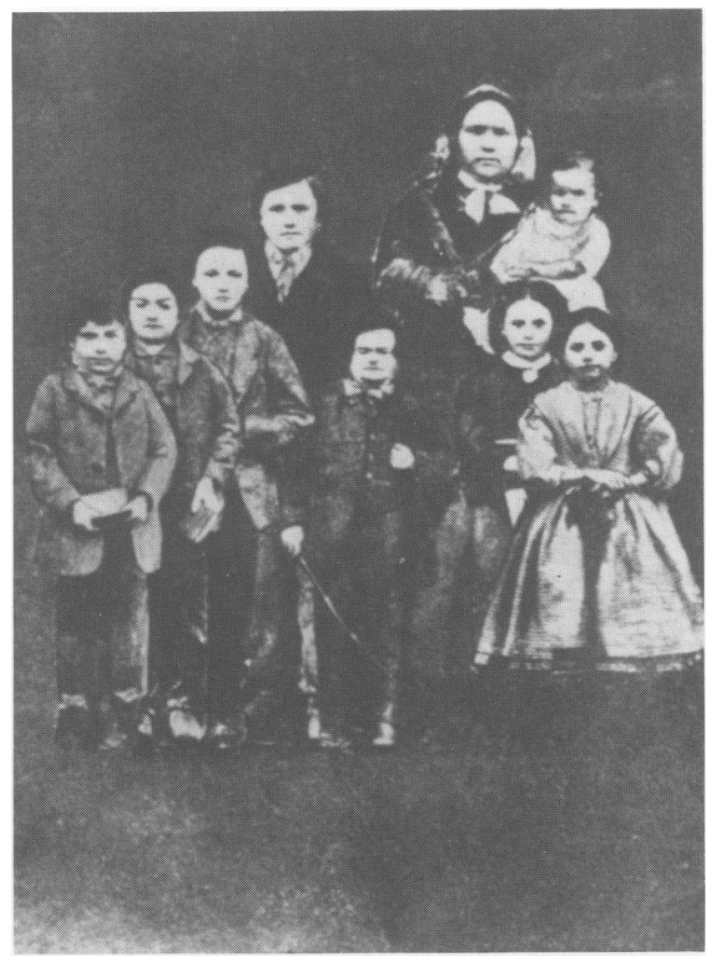

Figure 7 Teiliwr bach Dihewyd and his family, chosen by Sir John to demonstrate the African pygmy origins of the Welsh people. Sequel from 'Key of all Wales', 1932, bearing the imprint of the Western Mail, with permission.

piece of evidence was the discovery of a round wooden ball amongst the stones in front of an old tithe barn, known as Ydlan y Degwm. This he decided must be the very ball used to play knappan, the game described by Thomas Phaer and which Sir John now claimed to be Trojan in origin. When he asked the National Museum of Wales for verification, he was undismayed when in reply they asked him to send the stick along as well! They are remarkable documents, but they are not in Sir William's library for he never saw them.

\section{The College of Librarianship at Aberystwyth}

Oslerians will recognize the inevitability of $\mathrm{Sir}$ William Osler's association with the books and libraries of Wales. In his sixties, he made several visits to the Sir Thomas Phillipps Library, then at Thirlestaine House near Cheltenham, and he records purchases of medical manuscripts in 1911, 'all from the Phillips (sic) sale (but I am ruined!).'18

He was amongst those who encouraged the foun- 
dation of the College of Librarianship at Aberystwyth, a college which has since won international reputation. On 31st July, 1917, Sir William addressed delegates at the opening of the Summer School of Library Services at Aberystwyth. He told them that 'The outlook for your profession is bright, and you may help to make it brighter here in Wales by encouraging in every way the improvement of the conditions under which you work. One thing I should dearly like to see - an up-to-date School of the Book in connection with the National Library and this College; and if anything I have said here hastens its establishment I will feel in Lucian's words "that I shall have had a share in its building if not in the dedicatory inscription; my

\section{References}

1. Owen, G. In: (ed. Henry Owen) The Description of Pembrokeshire. London, 1892, I, p. 279.

2. Cushing, H. The Life of William Osler, chapter 1. Oxford University Press, London, New York, Toronto, 1940.

3. Gittings, R. Edward Osler and John Keats. In: Cule, J. (ed) Wales and Medicine. Llandysul, 1975, pp. 107-111.

4. Ware, J. \& Hunt, H. The Several Lives of a Victorian Vet. London, 1979, pp 56, 99.

5. Henle, J. Von den Miasmen und Contagien. In: Pathologische Untersuchungen. Berlin, 1840, pp 1-82.

6. Koch, R. Die Aetiologie der Tuberculose. Berl klin Wochenschr 1882, 15: 224. For translation see Clendening, L. Source Book of Medical History. Dover Publications, New York, 1960, p 399.

7. National Library of Wales. Griffith Evans MS III contains "Report on "Surra" disease ... dated Simla, 13th November 1880'. p 61. para 8.

8. National Library of Wales. Griffith Evans MS III contains "Report on "Surra" disease... dated Simla, 13th November 1880'. pp 65-66, para 24.

9. Cule, J. 'The postulates' of Griffith Evans, M.D., M.R.C.V.S. (1835-1935) and the Specificity of Disease. In: Kerkhoff, A.H.M., Luyendijk-Elshout, A.M. \& Poulissen, M.J. (eds) De Novis Inventis. Essays in the History of Medicine in Honour of Daniel de Moulin... Holland University Press, Amsterdam, 1984, pp 81-93. finger-tips will at least have touched their wet mortar".'19

\section{Egerton Yorrick Davis, M.D.}

The speculation that this friend of WO was identical with Egerton Iorwerth Davies, an emigré from Treherbert seems to have no foundation and cannot be claimed as the last Welsh connection.

\section{Acknowledgement}

I am grateful to my colleage, Professor Ralph Marshall, of the Department of Medical Illustration, for his help with the illustrations.

10. National Library of Wales. Griffith Evans MS III. 'Holograph letter from William Osler to Griffith Evans.'

11. Holograph letter from Edwin Seward to Lady Osler, dated March 1st, 1923. University of Wales College of Medicine.

12. The Welsh National School of Medicine. Inaugural Proceedings at Cardiff, 12th August, 1915. [Cardiffo Western Mail dated 1915].

13. Cushing, H. The Life of William Osler, Oxfort. University Press, London, New York, Toronto, 1940 pp 1097, 1098n, 1277.

14. Evans, D.E. The University of Wales. University of Wales Press, Cardiff, 1953, pp 104-105.

15. Cushing, H. The Life of William Osler, Oxford University Press, London, New York, Toronto, 1940, p 1210.

16. Jones, G.R. The King Edward VII National Memorial Association 1912-1948. In: Cule, J. (ed) Wales and Medicine. Llandysul, 1975.

17. Cushing, H. The Life of William Osler, Oxford University Press, London, New York, Toronto, 1940, p 1218.

18. Cushing, H. The Life of William Osler, Oxford University Press, London, New York, Toronto, 1940, p 957.

19. Osler, Sir William, The Library School in the College. The Library Association Record, 19, 1917: p 308. 